\title{
LIQUID COMPLEX FERTILIZERS ON THE CULTURES OF AGRICULTURAL CULTURES OF THE BLACK SEA STEP OF UKRAINE
}

\section{Krivenko A. I.}

\section{INTRODUCTION}

In Ukraine, the production of liquid complex fertilizers (LCF) of the brands 11:37 and 10:34 (nitrogen: phosphorus), in which phosphorus is presented in the form of ammonium ortho- and polyphosphates, is set up again, with the share of the latter being 65-75\%. Polyphosphates become available to plant roots after their transformation under the action of the soil enzyme pyrophosphatase, while phosphor phosphate is available to plants directly. Managers of agricultural enterprises are attracted by their numerous advantages ${ }^{1}$ :

- can be brought to the soil surface without the need for immediate tillage; compared to solid fertilizers more evenly distributed over the surface of the field; uniformity of composition: each drop of liquid fertilizer has the same composition;

- other components (microelements, growth regulators, pesticides) can be introduced into their composition, with the added components being distributed throughout the fertilizer and this allows them to be introduced as evenly as possible;

- in comparison with liquid nitrogen fertilizers LCF do not contain free ammonia, so they can be transported and stored in leaky containers;

- works with the LCF are fully mechanized, losses during overloading and storage do not exceed $1 \%$, whereas for solid fertilizers this figure is $10-15 \%$ and more;

- the cost of LCF is lower than solid fertilizers due to the exclusion of energy-intensive technological stages (granulation, drying, dust collection, etc.).

In the period up to 1990, agricultural research institutions have shown in numerous experiments the high efficiency of the use of LCFand CAS(Ammoniac mixture) for basic crops ${ }^{2}$. But over time, there have been and

1 Loginova I. (2016) Liquid complex fertilizers. Agronomist. No. 2 (52). URL: https: //agronom.com.ua/zhydkye-kompleksnye-udobrenyya/.

${ }^{2}$ Getmanets A.Ya., Kramarev S.M., Bondar V.P., Usenko Yu.I. (1990) Efficiency of coapplication of liquid complex fertilizers and herbicides in crops of corn cultivated using intensive technologies. Collection of scientific papers of the All-Russian Research Institute of Corn. S. 55-62; Kramarev S.M. (1990) The effect of co-administration of LCF, KAS-28 and herbicides on some 
are changing climatic conditions, soil fertility, and some elements of cultivation technologies are being improved, which necessitates an assessment of the efficiency of the LCF for the present.

Active and scientifically based use of LCF in some measure will help to solve the problem of phosphorus state of the black soil of Ukraine. According to statistics, between 1966 and 1990, the use of phosphorus fertilizers increased steadily and reached $40 \mathrm{~kg}$ of active substance per hectare . In this case, the weighted average content of mobile phosphorus in the steppe zone increased from $67 \mathrm{mg}$ per $1 \mathrm{~kg}$ of soil to $93 \mathrm{mg} / \mathrm{kg}$.

A sharp decrease in the level of application of phosphorus fertilizers begins in 1991 and already in 1997 it amounted to $4.1 \mathrm{~kg} \mathrm{bw} / \mathrm{ha}$; the annual deficit of mineral phosphorus reached $15-20 \mathrm{~kg} / \mathrm{ha}(4-5 \mathrm{mg} / \mathrm{kg})^{3}$. The minimum amount of phosphorus fertilizers (2-3 kg/ha) was introduced in 2000-2003, since 2004 the gradual increase in the volumes of introduction of phosphorus fertilizers began, although it remained unacceptably low (7-10 kg/ha).

Under the harvest 2017-2019. in the Odessa region, phosphorus fertilizers of 5-6 kg dw/ha were introduced and in the total amount of mineral fertilizers introduced the share of phosphorus was $18 \%$, potassium $-14 \%$ and nitrogen $-68 \%$.Prolonged application of low rates of phosphorus fertilizers has led to a significant deterioration of the phosphate regime of soils of Ukraine as a whole and of the Steppe zone as well.

\section{Material and Methods}

To determine the effectiveness of liquid complex fertilizers (LCF) 10: 34: 0 in the conditions of the Black Sea agricultural zone of the Odessa region were done trial with the main crops in the field of field crop rotation: corn for grain, peas, winter wheat, sunflower.

In addition, LCF was applied into black fallow and explored the possibility of its use for pre-sowing seed treatment as an adhesive.

Soil of the trial field of the Odessa State Agricultural Experimental Station - chernozem southern low humus heavy loam.

The arable layer of the experimental plot was characterized by the following indicators: humus content $-3.11 \%$, mobile phosphorus and

physiological and photosynthetic indicators of corn plants. Alma-ata. Thes. doc. (Republican scientific and practical conference of young scientists and specialists). S. 117-118; Nevskaya V.N. (1988) CAS solutions with trace elements, nitrification inhibitors, and pesticides. Chemicalization. Number 3. S. 30-32; Radchenko V.V., Berezina N.L. (1988) Specialization issues in the use of solid and liquid mineral fertilizers. Improving the economic mechanism in the agricultural sector. Thes. reports of the 2nd Belarusian scientific and practical. conf. young scientists and specialists. Minsk. S. 477-478.

${ }^{3}$ Kramaryov S. Phosphor, the problem of Ukrainian black soil and the possibility of hatches of the Russian Federation. Farmer. URL: https://imptorgservis.uaprom.net/a170873fosforna-problema-ukrayinskih.html. 
potassium - $100.0 \mathrm{mg} / \mathrm{kg}$ soil and $105.0 \mathrm{mg} / \mathrm{kg}$, respectively. The size of the plot is 140 square meters, the accounting area is $84.0 \mathrm{~m}^{2}$, the repetition rate is four times. In the trials was used recognized variety.

Fertilizers were used as ammonium nitrate, simple granulated superphosphate, potassium salt and LCF 10: 34: 0 . Schemes of experiments on individual cultures are given in the presentation of the results. Time of experiments 2018-2019 agricultural year.

\subsection{Weather conditions of time of experiments}

Summarizing long-term meteorological data it is proved that in the Odessa region $444 \mathrm{~mm}$ of precipitation falls during the year. It should be noted that rainfall is very unevenly distributed, leading to an acute shortage of moisture and a sharp decrease in yield. During the summer, $34-40 \%$ of the total annual rainfall occurs, and in other seasons fall by $20 \%$, which emphasizes a distinct continental character.

The hydrothermal coefficient of the Black Sea Steppe is 0.5-0.8. According to long-term observations of the Odessa Hydrometeorological Station, the frost-free period lasts 175-180 days, the sum of effective air temperatures (above $+10^{\circ} \mathrm{C}$ ) is $3200-3400$ o.

The average annual air temperature is $9-10^{\circ} \mathrm{C}$. The rainfall here is $330-380 \mathrm{~mm}$. Precipitation is a very variable element of the climate of the area. Their distribution during the growing season, both in time and in intensity is very uneven, which prevents their effective use.

The productivity of the crop industry, as well as of agriculture in general, depends to a large extent on the influence of climatic factors, especially on the amount and uniformity of the rainfall, as well as on the temperature and relative humidity. March 2019 was at the level of 2015 (Picture 1). The average monthly temperature in the south of Ukraine for this month was $5.0^{\circ} \mathrm{C}$, which is higher than the long-term norm by $2.3^{\circ} \mathrm{C}$. For comparison, we show the average monthly outdoor air temperature in March for the last 5 years.

This year, the transition of the average daily air temperature through the mark of plus five degrees, which is considered to be during the steady spring resumption of the vegetation of winter crops in the conditions of the Odessa Agricultural Experimental Station, was noted on March 17, which was noticeably earlier than last year - March 31 and later in Compared with 2017 March 5. In general, in April there was a rapid increase in heat in the third decade. If in the first ten days of April it was $6.7^{\circ} \mathrm{C}$, in the second $7.7^{\circ} \mathrm{C}$, and in the third $-14.5^{\circ} \mathrm{C}$ (Picture. 2). The average temperature for the month was $9.8^{\circ} \mathrm{C}$, which corresponds to a long-term norm.

In May, a high air temperature was observed with an excess of the average annual norm of $4.8^{\circ} \mathrm{C}$. The ten-day increase in temperature was gradual: in the 1 st decade, the temperature was $11.3^{\circ} \mathrm{C}$, in the $2 \mathrm{nd}$ decade $16.3^{\circ} \mathrm{C}$ and in the $3 \mathrm{rd}-20.5^{\circ} \mathrm{C}$. 


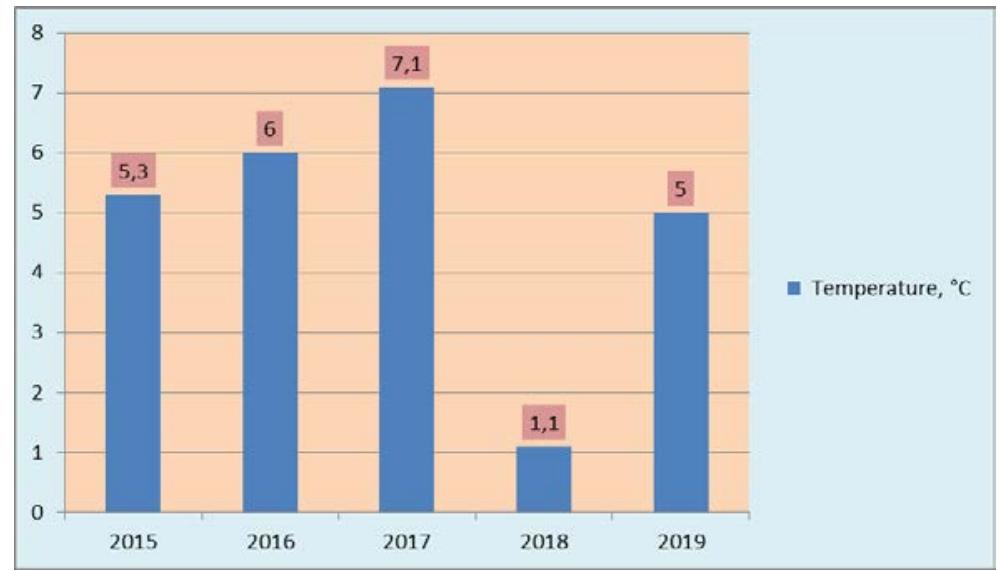

Pic. 1. The average monthly air temperature in March for the last 5 years, ${ }^{\circ} \mathrm{C}$

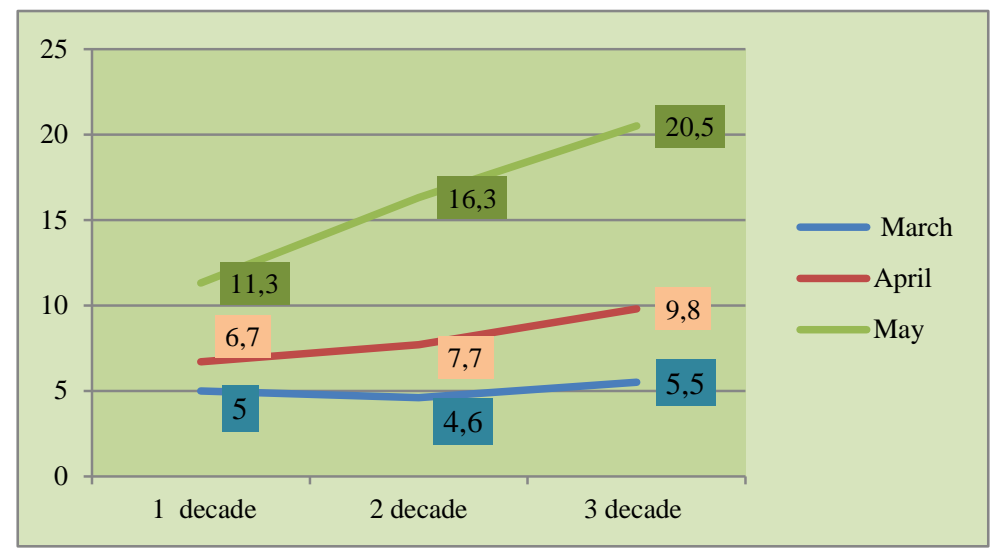

Pic. 2. Ten-day average air temperature in the spring of 2019 according to the weather station of Odessa State Agricultural Experimental Station

The spring period of 2019 turned out to be largely arid: in March there was no precipitation (Picture. 3), in April it fell in the second decade (23 mm), which is $10.3 \mathrm{~mm}$ lower than the average long-term norm; in May there was very little rainfall of $-10.5 \mathrm{~mm}$ (28.7\% of the average annual norm). The lack of precipitation in sufficient quantities and the high temperatures of the spring period negatively influenced the growth and development of all crops. 


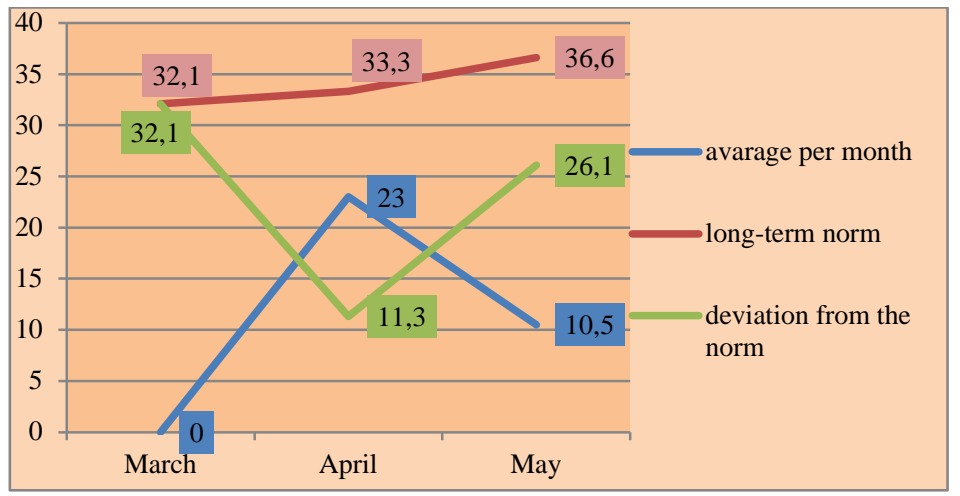

Pic. 3. Long-term average rate and monthly precipitation in the spring of 2019

\section{Results}

\subsection{Corn for grain}

The equivalence of LCF and solid mineral fertilizers for corn is shown in Table 1 . There was a tendency to an increase in yield $(+2.8 \mathrm{c} / \mathrm{ha})$ during the spring application of liquid complex fertilizers before sowing corn in combination with the main nitrogen-potassium fertilizer in comparison with the similar option, where liquid complex fertilizers served as the main fertilizer (options 3.4).The use of liquid complex fertilizers in its pure form led to a certain decrease in yield relative to its integrated application, but there was also a tendency to higher yields during spring to sowing. The use of liquid complex fertilizers for top dressing in phase 12-17 (according to the European classification of $\mathrm{BBCH}$ ) increased the yield in comparison with the pure control by $7,1 \%$.

An analysis of the available nutrients in the soil by the phases of corn organogenesis showed a higher content of mobile phosphorus in the variants of spring application of LCF and in top dressing: on average, the excess was from $43.5 \%$ ( 5 days after application) and $10.9 \%$ after 20 days, both in relation to pure control, and to solid mineral fertilizers. In the content of available forms of nitrogen, no significant differences were observed.

The nitrogen content in the corn grain of all variants was slightly (1.3 ... 10.3\%) higher than the control variant, but the maximum protein yield per unit area was observed in the variants where phosphorus in the composition of solid mineral fertilizer was replaced by $10: 34$ equivalent grade liquid-fat formative agents and applid LCF in the spring before sowing or in top dressing in phase $12-17 \mathrm{BBCH}$. The excess was $26.8 \%$ and $31.6 \%$ compared with the pure control and $8.1 \%, 12.2 \%$ - in relation to the main application of solid mineral fertilizers. 
Table 1

Harvest of corn grain, depending on the form of fertilizers, $\mathrm{kg} / \mathrm{ha}$

\begin{tabular}{|c|c|c|c|c|c|c|c|c|}
\hline \multirow{2}{*}{$\begin{array}{c}\text { № } \\
\text { plot }\end{array}$} & \multirow{2}{*}{ Option Content } & \multicolumn{4}{|c|}{ repetition } & \multirow{2}{*}{ Average } & \multicolumn{2}{|c|}{ \pm control } \\
\hline & & $\mathbf{I}$ & II & III & IV & & t/ha & $\%$ \\
\hline 1. & $\begin{array}{l}\text { Control } \\
\text { (without fertilizer) }\end{array}$ & 42,4 & 43,0 & 41,2 & 41,4 & 42,0 & - & \\
\hline 2. & N90P60P60 * & 47,6 & 49,2 & 48,3 & 49,5 & 48,6 & 6,6 & 15,7 \\
\hline 3. & LCF $* *+\mathrm{NP}$ & 46,1 & 49,1 & 50,6 & 47,4 & 48,3 & 6,3 & 15,0 \\
\hline 4. & $\begin{array}{l}\text { LCF in the spring } \\
\text { before crops + NP the } \\
\text { main application }\end{array}$ & 49,8 & 52,6 & 52,4 & 49,7 & 51,1 & 9,1 & 21,9 \\
\hline 5. & $\begin{array}{l}\text { LCF in top dressing + } \\
\text { NP the main application }\end{array}$ & 51,1 & 51,1 & 49,5 & 49,8 & 50,4 & 8,4 & 20,0 \\
\hline 6. & $\begin{array}{l}\text { Liquid Complex } \\
\text { Fertilizers in the fall - } \\
\text { the main }\end{array}$ & 47,3 & 46,9 & 45,5 & 46,9 & 46,6 & 4,6 & 11,0 \\
\hline 7. & $\begin{array}{l}\text { Liquid Complex } \\
\text { Fertilizers in the spring } \\
\text { before crops sowing }\end{array}$ & 45,6 & 47,8 & 47,4 & 48,0 & 47,2 & 5,2 & 12,4 \\
\hline 8. & LCF in top dressing & 44,7 & 44,3 & 45,2 & 45,9 & 45,0 & 3,0 & 7,1 \\
\hline \multicolumn{8}{|c|}{ experimental error, $\%$} & 1,5 \\
\hline \multicolumn{8}{|c|}{ Least significant difference $95 \%\left(\operatorname{LSD}_{0,95}\right)$} & 2,0 \\
\hline
\end{tabular}

* - solid mineral fertilizers (SMF) - the main application in the fall;

** - LCF is normally equivalent to P60 (in all cases) and NP is equivalent to option 2 (in all cases) - main application.

\subsection{Peas}

In preliminary studies in a long stationary experiment, we found ${ }^{4}$ that to obtain a high yield of peas in a crop rotation with organic fertilizers directly under the peas, it is sufficient to apply phosphorus-potassium fertilizers. But, since according to the last round of agrochemical examination, the soils of most agricultural enterprises in Odessa region have sufficient reserves of exchange potassium and an insufficient potential for producing available nitrogen, as well as a low content of mobile phosphorus, then under such conditions liquid complex fertilizers grade 10:34 should be ideal for this culture.

The excess of the pea grain harvest relative to the pure control in the variants with liquid complex fertilizers(LCF) application was 22,9\% and $28,2 \%$, relative to solid mineral fertilizers (SMF) $-5,55$ and $10,1 \%$, moreover, higher growths were observed when using LCF in the spring before sowing

${ }^{4}$ Burikina S.I. (2009) Norms of payback - the basis for formulating the regulatory framework for planning and forecasting the development of crops. Newsletter of agrarian science of the south region. Odessa: SMIL, 2009. Issue 10, pp. 9-13. 
the crop. Due to the higher yield, the protein yield per unit area also increased - by $19,7 \%$ and $26,7 \%$ relative to the variant without fertilizers and small (2,5\% and $8,5 \%)$, but still an excess compared to SMF. The absolute nitrogen content in the pea grain varied according to the experimental variants in a narrow range of values $-3,39 \ldots 3,49 \%$.

Table 2

The Impact of the terms of liquid complex fertilizers on the crop and the main indicators of the quality of pea grain, variety Light

\begin{tabular}{|c|c|c|c|c|c|c|c|c|}
\hline \multirow{3}{*}{$\begin{array}{l}\text { № } \\
\text { plot }\end{array}$} & \multirow{3}{*}{ Option Content } & \multicolumn{5}{|c|}{ Harvest, c/ha } & \multirow{3}{*}{$\begin{array}{l}\text { Weight } \\
1000 \\
\text { seeds, } \\
\text { grams }\end{array}$} & \multirow{3}{*}{$\begin{array}{l}\text { The } \\
\text { yield of } \\
\text { protein, } \\
\text { kg/ha }\end{array}$} \\
\hline & & \multicolumn{4}{|c|}{ Repetition } & \multirow{2}{*}{ Average } & & \\
\hline & & I & II & III & IV & & & \\
\hline 1. & $\begin{array}{l}\text { Control } \\
\text { (without fertilizer) }\end{array}$ & 18,8 & 19,3 & 18,3 & 19,0 & 18,8 & 224,1 & 408,9 \\
\hline 2. & $\begin{array}{l}\text { N20P68 - main } \\
\text { application }\end{array}$ & 21,2 & 21,5 & 22,8 & 22,0 & 21,9 & 231,8 & 477,7 \\
\hline 3. & $\begin{array}{l}\text { LCF, } 200 \mathrm{~kg} / \mathrm{ha} \\
\text { physical. weights - } \\
\text { the main application }\end{array}$ & 22,5 & 22,3 & 24,2 & 23,4 & 23,1 & 231,3 & 489,4 \\
\hline 4. & $\begin{array}{l}\text { LCF, } 200 \mathrm{~kg} / \mathrm{ha} \\
\text { physical. weights - } \\
\text { in the spring before } \\
\text { sowing }\end{array}$ & 24,4 & 24,2 & 23,6 & 24,1 & 24,1 & 231,8 & 518,2 \\
\hline \multicolumn{6}{|c|}{ experimental error,\% } & 1,7 & 3,8 & - \\
\hline \multicolumn{6}{|c|}{ Least significant difference 0,95} & 1,1 & 5,6 & - \\
\hline
\end{tabular}

The content of mobile forms of nitrogen in the soil of the control variant is lower than in the experimental plots. The concentration of ammonia nitrogen in the flowering phase was higher when applying LCF, both in the main application and when sowing in comparison with the variant of fertilizers by $70 \%$ and $63 \%$, and in comparison with the main application of solid mineral fertilizers by 30,8 and 28,5 percent. To full ripeness, the content of ammonium nitrogen decreases to very small values $(1 \ldots 4 \mathrm{mg} / \mathrm{kg})$, but the patterns remain.

A relatively higher content of nitrate nitrogen in the soil layer of 0-30 cm is observed in Flowering during the main application of SMF; to full ripeness, the difference in its concentration by fertilizer options is almost leveled. At the same time, the nitrification ability, which characterizes the level of accumulation of nitrate nitrogen in the soil when it is composted for 14 days under optimal temperature conditions and moisture, is in the option of pre-sowing application of LCF by the end pea vegetation, almost twice exceeded the net control (1.8 times) and the options for the main application of both SMF and LCF 
(by $61.5 \%$ and $53.7 \%$, respectively). By the flowering phase, the differences in soil nitrification ability in the control variant and with the main addition of SMF were insignificant (4.8\% higher in the second case); the basic application of LCF exceeded SMF with the same method of application by $23,0 \%$ and by $16,3 \%$ LCF when applied before sowing peas. Obviously, the application of LCF brand 10:34 activates the nitrifying microflora of the southern chernozem, regardless of the period of application.

The utilization rate of fertilizer phosphorus by pea plants during the main application of SMF was 2.5 times lower than with the LCF 10:34 with the same application period.

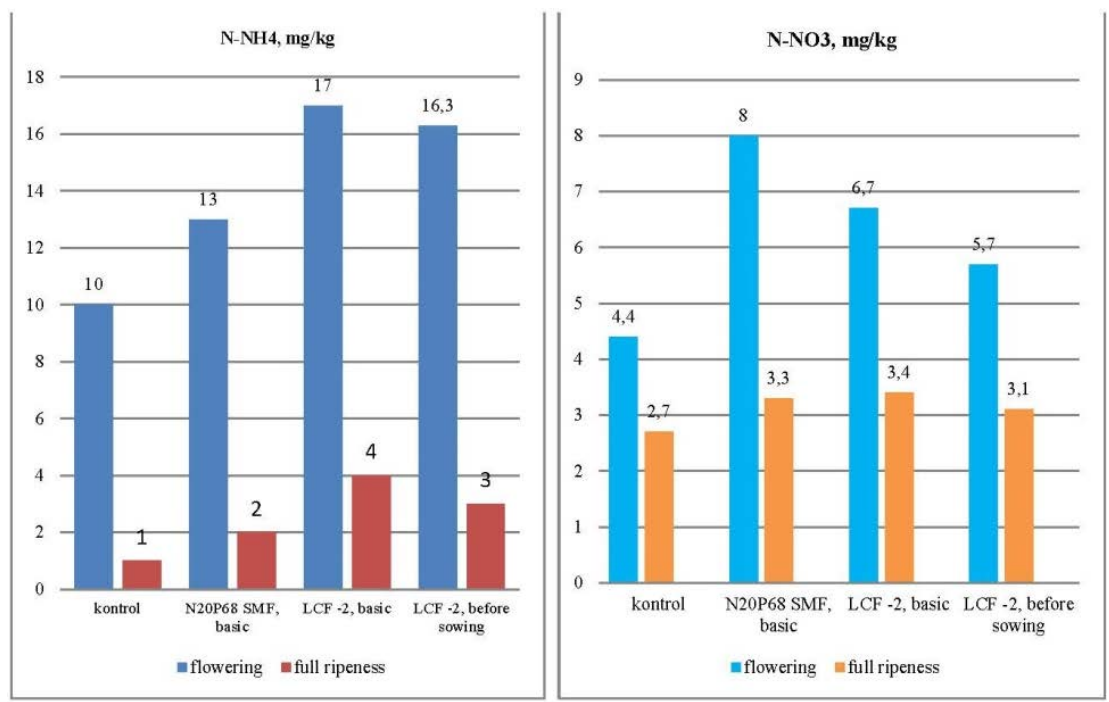

Pic. 4. The content of ammonium and nitrate nitrogen under sowing peas (layer 0-20 cm)

\subsection{Winter wheat pre-crop peas}

Options for experience:

1. Control of fertilizers;

2. $\mathrm{N}_{60} \mathrm{P}_{30} \mathrm{~K}_{60}$ - the main application of solid mineral fertilizers background;

3. Background $+\mathrm{N}_{15} \mathrm{P}_{51 \text { - }}$ solid mineral fertilizer was applied locally at the beginning of spring tillering;

4. Background + LCF is equivalent to $\mathrm{N}_{15} \mathrm{P}_{51}$ - foliar application to plants at the beginning of spring tillering;

5. Background + LCF is equivalent to $\mathrm{N}_{15} \mathrm{P}_{51}$ foliar application to plants in the phase of the beginning of exit into the tube. 
The grain yield of winter wheat Cantata variety when grown on peas amounted to 45,7 c/ha without fertilizing, against the background of SMF $53,6 \mathrm{c} / \mathrm{ha}$. When the top dressing was introduced in the form of SMF, the grain yield increased to 55,6 c/ha, the same was the crop when using LCF for spring top dressing (55,6 c/ha). Using the background of the main application of LCFin the phase of the beginning of the exit to the tube, 54,4 c/ha of winter wheat was obtained. The yield growth due to top dressing amounted to (t/ha) 2,9; 2,9 and 0,8 , and due to the whole norm $-9,9 ; 9,9$ and 7,3 with a LSD of $0,95=1,7 \mathrm{c} / \mathrm{ha}$.

The physical quality parameters of winter wheat grains such as the mass of 1000 kernels and bulk density did not differ significantly in the options for the use of LCF, and in the case of the background fertilizer, the mass of 1000 kernels significantly less control without fertilizers (table 3).

The vitreousness of the grain from the plots of fertilizer application did not differ, but in relation to the non-fertilized version - they are significantly higher.

Table 3

Quality of winter wheat grains with various technologies for making housing and communal services

\begin{tabular}{|c|c|c|c|c|c|c|c|}
\hline $\begin{array}{c}\text { No } \\
\text { plot }\end{array}$ & $\begin{array}{c}\text { Weight } \\
\mathbf{1} \text { liter, } \\
\text { grams }\end{array}$ & $\begin{array}{c}\text { Weight } \\
\mathbf{1 0 0 0} \\
\text { grains, } \\
\text { grams }\end{array}$ & $\begin{array}{c}\text { vitreousness, } \\
\mathbf{\%}\end{array}$ & $\begin{array}{c}\text { Gluten, } \\
\mathbf{\%}\end{array}$ & $\begin{array}{c}\text { protein, } \\
\mathbf{\%}\end{array}$ & $\begin{array}{c}\text { Protein } \\
\text { harvest, } \\
\mathbf{k g} / \mathbf{h a}\end{array}$ & $\begin{array}{c}\mathbf{P}_{\mathbf{2}} \mathbf{O}_{\mathbf{5}}, \\
\mathbf{\%}\end{array}$ \\
\hline 1. & 795,2 & 45,8 & 82,5 & 19,9 & 11,32 & 517,3 & 0,71 \\
\hline 2. & 793,5 & 42,6 & 96,0 & 26,4 & 13,31 & 713,4 & 0,79 \\
\hline 3. & 799,0 & 44,3 & 97,5 & 29,6 & 13,82 & 768,4 & 0,79 \\
\hline 4. & 800,0 & 44,6 & 98,0 & 33,2 & 15,12 & 840,7 & 0,86 \\
\hline 5. & 797,8 & 43,0 & 98,5 & 31,1 & 14,87 & 808,9 & 0,91 \\
\hline $\mathrm{LSD}_{0,95}$ & 12,6 & 2,9 & 4,0 & 3,0 & 1,02 & - & 0,14 \\
\hline
\end{tabular}

In terms of gluten content, applying fertilizers had a significant advantage, both in relation to the control and the background variant, and a significant increase in protein concentration in winter wheat grain in relation to the main use of SMF was observed during the feeding of LCF in both of the studied vegetation phases. The phosphorus content in the grain significantly exceeded the control also in the case of using LCF for spring feeding (table 3).

\subsection{Sunflower}

The experiment with sunflower was carried out according to a scheme similar to peas, the difference consisted in the dose of fertilizers. $\mathrm{N}_{30} \mathrm{P}_{102}$ was added under the sunflower, which amounted to $300 \mathrm{~kg} / \mathrm{ha}$ of physical weight in the form of LCF. The crop increased from $24,0 \mathrm{c} / \mathrm{ha}$ in the control to 
$26,6 \mathrm{c} /$ ha with the introduction of solid mineral and up to $27,0-27,8 \mathrm{c} / \mathrm{ha}$ with the application of LCF. Crop growth with the use of LCF amounted to $4,3-5,3 \mathrm{c} / \mathrm{ha}$, SMF $-3,1 \mathrm{c} / \mathrm{ha}$ with a LSD of $0,95=1,1 \mathrm{c} / \mathrm{ha}$.In the arid conditions of 2019, sunflower seeds were small: the mass of 1000 seeds from the fertilized varieties did not go beyond 69,2-701 grams against 65,8 grams on unfertilized ones. Seed huskiness was $21,6-21,8 \%$ versus $22,5 \%$.

The fat content in the core $(56,32-57,17 \%)$ did not differ much in fertilizer options, but its collection from 1 ha significantly (by 11,3-12,9\%) increased in the plots of the main fertilizer application, including when apply LCF for sowing - by $15,8 \%$.The utilization rates of phosphorus from liquid fertilizers were 1,8-2,0 times higher than from solid mineral fertilizers at equal application doses.

\subsection{Using liquid complex fertilizers in the black fallow}

In 2018, in a specially designated area for the trial with black fallow, fertilizers were applied according to the scheme shown in table 4.

The presence of mobile nutrients in the soil under fallow

\begin{tabular}{|c|c|c|c|c|c|c|c|c|}
\hline \multirow{3}{*}{$\begin{array}{l}\text { № } \\
\text { plot }\end{array}$} & \multirow{3}{*}{$\begin{array}{l}\text { Option } \\
\text { Content }\end{array}$} & \multirow{3}{*}{$\begin{array}{l}\text { Sample } \\
\text { Depth, } \\
\text { cm }\end{array}$} & \multicolumn{3}{|c|}{$\begin{array}{c}\text { Sample in fallow } \\
18.052019\end{array}$} & \multicolumn{3}{|c|}{$\begin{array}{c}\text { Sample in germinate } \\
\text { winter wheat - } \\
11.10 .2019\end{array}$} \\
\hline & & & $\mathrm{N}-\mathrm{NO}_{3}$ & $\mathbf{P}_{2} \mathbf{O}_{5}$ & $\mathrm{~K}_{2} \mathrm{O}$ & $\mathrm{N}-\mathrm{NO}_{3}$ & $\mathbf{P}_{2} \mathbf{O}_{5}$ & $\mathbf{K}_{2} \mathbf{O}$ \\
\hline & & & \multicolumn{6}{|c|}{ mg per kg of soil } \\
\hline \multirow{3}{*}{1.} & \multirow{3}{*}{ No fertilizer } & $0-10$ & 13,2 & 100,0 & 125,0 & 7,0 & 112,5 & 150,0 \\
\hline & & $10-20$ & 9,7 & 87,5 & 95,5 & 5,8 & 120,0 & 150,0 \\
\hline & & $20-40$ & 8,9 & 87,5 & 77,5 & 4,3 & 120,0 & 77,5 \\
\hline \multirow{3}{*}{2.} & \multirow{3}{*}{$\begin{array}{l}\mathrm{N}_{30} \mathrm{P}_{102}-\mathrm{SMF} \text { when } \\
\text { fallow was plowing }\end{array}$} & $0-10$ & 20,8 & 147,5 & 135,2 & 8,9 & 112,5 & 120,0 \\
\hline & & $10-20$ & 20,4 & 85,0 & \begin{tabular}{|l|l}
101,2 \\
\end{tabular} & 8,0 & 107,5 & 95,0 \\
\hline & & $20-40$ & 8,5 & 87,5 & 72,5 & 6,0 & 95,0 & 105,0 \\
\hline \multirow{3}{*}{3.} & \multirow{3}{*}{$\begin{array}{l}\mathrm{N}_{30} \mathrm{P}_{102}-\mathrm{LCF} \text { with } \\
\text { equalization of black } \\
\text { fallow in the fall }\end{array}$} & $0-10$ & 19,0 & 147,5 & 135,5 & 8,9 & 162,5 & 192,5 \\
\hline & & $10-20$ & 7,5 & 92,5 & 91,5 & 6,0 & 140,0 & 185,0 \\
\hline & & $20-40$ & 6,6 & 87,5 & 65,0 & 9,5 & 147,0 & 170,0 \\
\hline \multirow{3}{*}{4.} & \multirow{3}{*}{$\begin{array}{l}\mathrm{N}_{30} \mathrm{P}_{102} \mathrm{LCF} \text { in the } \\
\text { spring with black } \\
\text { fallow cultivation }\end{array}$} & $0-10$ & 21,7 & 132,5 & 135,5 & 10,8 & 125,0 & 185,0 \\
\hline & & $10-20$ & 8,3 & 105,0 & 135,5 & 10,8 & 125,0 & 157,5 \\
\hline & & $20-40$ & 5,1 & 112,5 & 72,5 & 5,6 & 100,0 & 170,0 \\
\hline \multirow{3}{*}{5.} & \multirow{3}{*}{$\begin{array}{l}\mathrm{N}_{30} \mathrm{P}_{102}-\mathrm{LCF} \\
\text { before sowing } \\
\text { of winter wheat }\end{array}$} & $0-10$ & 12,2 & 127,5 & 132,5 & 10,8 & 154,0 & 150,0 \\
\hline & & $10-20$ & 9,1 & 101,5 & 115,5 & 10,9 & 145,0 & 150,0 \\
\hline & & $20-40$ & 8,5 & 87,5 & 72,5 & 9,6 & 129,0 & 135,0 \\
\hline
\end{tabular}


When LCF was applied to black fallow in a soil layer of $0-20 \mathrm{~cm}$, slightly less nitrate nitrogen was contained in comparison with simple mixtures of solid mineral fertilizers in the spring of 2019. When LCF was applied before fallow cultivation and before winter wheat sowing, winter seedlings showed a higher content of nitrate nitrogen (by 21.3\%) in layers of $0-10 \mathrm{~cm}$ and $10-20 \mathrm{~cm}$, and the availability of mobile phosphorus to these soil layers was higher in all cases use of LCF.

\subsection{The use of LCF as an adhesive}

When dressing seeds of winter cereal crops even when diluted with water in a ratio of 1: 2 reduced laboratory and field germination by $4.0 \%$ to $12 \%$.

\section{Discussion}

In our studies on the southern chernozem, there was a significant difference in the agronomic efficiency of 10:34 LCF and solid mineral fertilizers when they are used on crops of corn and winter wheat, and only LCF on peas.

Nosov V.V. also notes that there is no difference in the effectiveness of liquid and solid phosphorus fertilizers in most soil types, therefore, the decision to use a particular product depends on its cost and ease of use in each specific condition. Nevertheless, according to the results of several studies, in some soil and climatic conditions (on carbonate soils), liquid phosphorus fertilizers, including ammonium polyphosphate, can have certain advantages over solid fertilizers ${ }^{5}$.

So, in his experiments on winter wheat with the addition of ammonium nitrate in the spring (N69), a yield of 7.32 t/ha was obtained, with the use of diammonium phosphate in the fall and ammonium nitrate in the spring with a total dose of N105P92 - 8.14 $\mathrm{t} /$ ha and with the application of LCF in autumn + in the spring, ammonium nitrate (N100-101P104-109) - $8.90 \mathrm{t} / \mathrm{ha}$.

Studies by the University of Minnesota (USA) showed that starting application of P-fertilizers for sugar beets is more effective than spreading. Starting application of $\mathrm{P}$ contributes to a better development of plants in the initial period of vegetation. A decrease in the dose of phosphorus at the initial application can reach 50\% compared with the introduction of scatter ${ }^{6}$.

${ }^{5}$ Nosov V. V. (2016) Efficiency of using diddy complex fertilizers containing ammonium polyphosphates. Plant nutrition. No. 1. S. 11-16.

${ }^{6}$ The effect of starting application of LCF 10-34-0 on sugar beet yield in the USA Adapted from: American Crystal Sugar Company URL: https: //www.crystalsugar.com/ media/18371/ag_starter_fertilizer_lr.pdf. 
At the day of the field in the Republic of Moldova ${ }^{7}$, many speakers noted such advantages of liquid phosphorus fertilizers as the convenience of storage on farms, as well as more accurate and more uniform application of phosphorus to the soil.According to the Lithuanian NIIZ, when applying LCF 10: 34: 0 under winter rye, the norm is $45 \mathrm{~kg}$ per 1 ha NP, the operating costs for the use of fertilizers were $17 \%$ lower than the application of the dry mix. Labor costs, in accordance with the accepted average costs for the use of LCF 10: 34: 0 , are 1.5 times less than for a mixture of double superphosphate ${ }^{8}$. In the experiments Marchenko L.A. and Mochkova T.V., the technologies of differential application of LCF and pesticides were developed and tested $^{9}$.As an effective way of introducing micronutrients, many researchers used the addition of micronutrient fertilizers in LCF solutions ${ }^{10}$. At the same time, they noted that each drop of the solution contains the same amount of components.Liquid ammonium polyphosphate, as in our experiments, was also successfully used for foliar application of plants ${ }^{11}$.

\section{CONCLUSIONS}

In the conditions of 2019:

- on corn crops, equivalent effect of LCF 10:34 and a mixture of simple solid fertilizers with main application were obtained; there was a tendency to an increase in grain yield, when LCF was introduced in the spring before sowing corn in addition to the main one (increase due to LCF was 2.8 centner/ha with LSD $0.95=2.0$ centner/ha);

- on peas of the Light variety, before sowing the application of LCF in the norm of N20P68, it had higher agronomic efficiency compared to the main application of the same dose of solid mineral fertilizers - the payback of $1 \mathrm{~kg}$ of active ingredient of LCF was $6.0 \mathrm{~kg} / \mathrm{kg}$, and SMF - $3.5 \mathrm{~kg} / \mathrm{kg}$;

- for sunflower, applying LCF 10:34 in the norm of $300 \mathrm{~kg}$ of physical weight per 1 ha (N30P102) was equivalent to solid mineral fertilizers during main application and insignificant advantage $(+0.8 \mathrm{c} / \mathrm{ha})$ of applying LCF before sowing before its main application was noted;

${ }^{7}$ Day of the sugar beet field (2017), Balti, Republic of Moldova, 06/14/2017. URL: http://eeca-ru.ipni.net/ipniweb/region/eecaru.nsf/\$FILE/Moldova_Sugar\%20beet_RUS.pdf.

${ }^{8}$ Application of liquid complex fertilizers URL: http: //agrohimija24.ru/compleksnyeudobreniya/2130-zhidkie-kompleksnye-udobreniya-i-ih-primenenie.html.

${ }_{9}^{9}$ Marchenko L.A., Mochkova T.V. (2009). Ecology and agricultural machinery. 2: 44-50.

${ }^{10}$ Krivoruchko G.I. (1989). Subtropical and ornamental horticulture, 36: 121-129; Fluid Fertilisers: A South Australian Manual. (2008). Holloway B., McLaughlin M., McBeath T., Kelly J. (eds). The University of Adelaide, GRDC, SARDI, CSIRO, Australia. 111 p.

${ }^{11}$ Sergeeva N.N. (2015). Leaf diagnostics in the technological apple fertilizer system. Scientific conference "Modern problems of horticulture intensification and innovative approaches to their solution". SKZNIISiV, Krasnodar.S. 9; Lynch J., Läuchli A., Epstein E. (1991). Crop Science. 31. 2.R. 380-387; Krivoruchko G.I. (1994). Subtropical and ornamental gardening. 38. S. 280-295. 
- the use of LCF in spring for foliar top dressing of winter wheat crops at a dose of N15P51 against the background of the main application of a mixture of solid mineral fertilizers at a dose of N60P30K60 was equivalent to solid mineral fertilizers in agronomic efficiency; the protein and gluten content in the grain, when used for top dressing of LCF, although it was significantly higher than when used for early spring top dressing of SMF, was within the requirements of one quality class (first).

\section{SUMMARY}

The article discusses the effectiveness of the use of liquid complex fertilizers based on ammonium polyphosphates in comparison with solid phosphorus fertilizers in the crop rotation link for corn - peas - winter wheat sunflower - black fallow in the Black Sea Steppe of Ukraine on the southern chernozem. According to research results, when applied to the crops of the main field crops, liquid ammonium polyphosphates have the same agronomic efficiency as solid phosphorus fertilizers.

Nevertheless, on peas, before sowing, application of LCF in the norm of N20P68 was more effective in comparison with the main application of the same dose of solid mineral fertilizers - the payback of $1 \mathrm{~kg}$ of active ingredient of LCF was $6.0 \mathrm{~kg} / \mathrm{kg}$, and SMF $-3.5 \mathrm{~kg} / \mathrm{kg}$.

The concentration of protein and gluten in winter wheat when grown with peas was significantly higher with early spring feeding of LCF 10:34 at a dose of N15P51 than when using a mixture of solid mineral fertilizers at the same dose and at the same time: protein $15.12 \%$ versus $13.82 \%$ (LSD $0.95=$ $1.02 \%$ ), gluten $-33.2 \%$ versus $29.6 \%$ with LSD $0.95=3.0 \%$, although in both cases the indicators remained within the requirements of the first quality class.

To apply of LCF before cultivation of fallow and before sowing winter wheat in pairs at a dose of N30P102 increased nitrate nitrogen content by seedlings of winter at $21.3 \%$ in layers of $0-10 \mathrm{~cm}$ and $10-20 \mathrm{~cm}$, and the supply of these soil layers with mobile phosphorus is higher in all cases use of LCF.

The utilization factors of phosphorus from LCF are 1.6-2.0 times higher than from solid mineral fertilizers with their equal application doses. 


\section{REFERENCES}

1. Loginova I. (2016) Liquid complex fertilizers. Agronomist. № 2(52). URL: https: //agronom.com.ua/zhydkye-kompleksnye-udobrenyya/ (accessed 05.10.2019).

2. Getmanets A.Ya., Kramarev S.M., Bondar V.P., Usenko Yu.I. (1990) Efficiency of co-application of liquid complex fertilizers and herbicides in crops of corn cultivated using intensive technologies. Collection of scientific papers of the All-Russian Research Institute of Corn. S. 55-62.

3. Kramarev S.M. (1990) The effect of co-administration of LCF, KAS-28 and herbicides on some physiological and photosynthetic indicators of corn plants. Alma-ata. Thes. doc. (Republican scientific and practical conference of young scientists and specialists). S. 117-118.

4. Nevskaya V.N. (1988) CAS solutions with trace elements, nitrification inhibitors, and pesticides. Chemicalization. № 3. S. 30-32.

5. Radchenko V.V., Berezina N.L. (1988) Specialization issues in the use of solid and liquid mineral fertilizers. Improving the economic mechanism in the agricultural sector. Thes. reports of the 2nd Belarusian scientific and practical. conf. young scientists and specialists. Minsk. S. 477-478.

6. Kramaryov S. Phosphor, the problem of Ukrainian black soil and the possibility of hatches of the Russian Federation. Farmer. URL: https://imptorgservis.uaprom.net/a170873-fosforna-problema-ukrayinskih. html (Cornered date 10/05/2019.).

7. Burikina S.I. (2009) Norms of payback - the basis for formulating the regulatory framework for planning and forecasting the development of crops. Newsletter of agrarian science of the south region. Odessa: SMIL, 2009. Issue 10, pp. 9-13.

8. Nosov V.V. (2016) Efficiency of using diddy complex fertilizers containing ammonium polyphosphates. Plant nutrition. No. 1. S. 11-16.

9. The effect of starting application of LCF 10-34-0 on sugar beet yield in the USA Adapted from: American Crystal Sugar Company URL: https://www.crystalsugar.com/media/18371/ag_starter_fertilizer_lr.pdf.

10. Day of the sugar beet field (2017), Balti, Republic of Moldova, 06/14/2017. URL: http://eeca-ru.ipni.net/ipniweb/region/eecaru.nsf/\$FILE/ Moldova_Sugar\%20beet_RUS.pdf.

11. Application of liquid complex fertilizers URL: http://agrohimija24.ru/compleksnye-udobreniya/2130-zhidkie-kompleksnyeudobreniya-i-ih-primenenie.html.

12.Marchenko L.A., Mochkova T.V. (2009). Ecology and agricultural machinery. 2: 44-50.

13.Krivoruchko G.I. (1989). Subtropical and ornamental horticulture, 36: 121-129. 
14. Fluid Fertilisers: A South Australian Manual. (2008). Holloway B., McLaughlin M., McBeath T., Kelly J. (eds). The University of Adelaide, GRDC, SARDI, CSIRO, Australia. 111 p.

15. Sergeeva N.N. (2015). Leaf diagnostics in the technological apple fertilizer system. Scientific conference "Modern problems of horticulture intensification and innovative approaches to their solution". SKZNIISiV, Krasnodar.S. 9.

16. Lynch J., Läuchli A., Epstein E. (1991). Crop Science. 31. 2.R. 380-387.

17. Krivoruchko G.I. (1994). Subtropical and ornamental gardening. 38. S. 280-295.

\section{Information about the author:}

Krivenko A. I.,

Candidate of Agricultural Sciences, Associate Professor,

Deputy Director for Scientific Work, Odessa State Agricultural Experimental Station of NAAN of Ukraine

24, Mayakskoe road str., smt Khlebodarskoe, Belyaevsky district, Odessa region, 67667, Ukraine

ORCID ID: 0000-0002-2133-3010 